\title{
Bedre kunnskap om smertebehandling
}

Smerter i en eller annen form er meget vanlig i befolkningen (1). Smerter kan være invalidiserende, men det er ofte ingen sammenheng mellom grad av påvisbar skade og smertenivå. Lette og kortvarige smerter kan til en viss grad anses som ufarlige, subjektive helseplager som vi alle er mer eller mindre sensitive for (2). Disse krever oftest ingen behandling, mens pasienter med moderate og sterke smerter som påvirker daglig funksjon, kan ha stor glede og nytte av adekvat behandling. Det er imidlertid mange som lider, og prevalensen av smerte synes å være økende (1). Mange søker til alternative behandlere (3).

I noen tilfeller kan smertens årsak ikke behandles, eller forblir ukjent. Det forskes mye på medikamentell behandling av smerte, og markedet for analgetika er svært stort. I tillegg er en lang rekke ikke-medikamentelle behandlingsmetoder i bruk. Noen ikke-medikamentelle behandlingsmetoder som transkutan elektrisk stimulering (TENS), ryggmargstimulering og kognitiv atferdsterapi (CBT) er eksempler på kunnskapsbaserte metoder som er tatt i bruk innenfor helsevesenet. Både i og utenfor helsevesenets rammer er en lang rekke ikke-medikamentelle metoder tatt i bruk for behandling av smerte, i mange tilfeller uten et tydelig kunnskapsbasert grunnlag. Behandling med ultralyd, laser, nåler (akupunktur) og massasje er noen eksempler.

Fagerlund og medarbeidere beskriver i dette nummer av Tidsskriftet kunnskapsgrunnlaget for transkranial elektrisk stimulering av hjernen og gir en oversikt over randomiserte studier av denne metodens effekt på kroniske smerter (4). Artikkelen viser tydelig at det er utført svært få gode studier av metoden, og dessverre med altfor få inkluderte pasienter. Den synes til en viss grad å være lovende, men det kreves flere, bedre og større studier for å avklare om transkranial elektrisk stimulering er nyttig i behandling av smerter.

Det er imidlertid en påfallende mangel på forskning på ikke-medikamentell behandling av smerter både nasjonalt og internasjonalt, selv om det finnes lyspunkter. Eksempelvis utføres det i Tromsø forskning på effekten av placebobehandling på smerter, og i Trondheim forskes det på bruken av transkranial magnetstimulering på migrene. Forskningen på ikke-medikamentelle metoder for smertelindring fremstår imidlertid som fragmentert, både i Norge og internasjonalt. De fleste aktuelle metoder har minimale bivirkninger, og forutsatt at man har tilgjengelig et visst minimum av støttepersonell kan randomiserte studier med blinding av både behandler og pasient la seg gjennomføre. Det mangler heller ikke på validerte verktøy for å måle effekten av behandlingen.

Et mulig angrepspunkt for ikke-medikamentell behandling av smerte er påvirkning av smertemodulerende mekanismer eller endring av kortikale reaksjonsmønstre. Transkutan elektrisk nervestimulering og ryggmargstimulering er antatt å virke gjennom påvirkning av smertemodulerende mekanismer $(5,6)$, mens kognitiv atferdsterapi antas å virke gjennom endring av kortikale reaksjonsmønstre (7). De siste årene har det vært forsket mye på både invasive og ikke-invasive hjernestimuleringsteknikker for behandling av smerte (8).

Transkranial magnetstimulering er vist å ha en effekt på migrene (9), og et apparat for slik behandling er allerede kommersielt tilgjengelig, riktignok uten formell godkjenning for behandling av smerter. Utstyret som kreves for denne typen ikke-medikamentell behandling er ikke veldig kostbart og vil raskt kunne tas i bruk av behandlere med lave krav til kunnskapsbasert nytteverdi. Det er flere eksempler på at behandling basert på nye teknologiske metoder er tatt i bruk uten kunnskapsbasert grunnlag, og metodene brukes gjerne i stort omfang før det etter lang tid slås fast at metodene er uvirksomme eller har svært beskjeden klinisk nytteverdi. Eksempler på dette er laserbehandling, perifer elektrisk muskelstimulering og pulsede magnetiske felter for kroniske smerter $(10,11)$.

Potensialet for kommersialisering av forskningsresultater vektlegges særskilt ved tildeling av forskningsmidler. Dette er bra og gir mulighet for utvikling av nye ikke-medikamentelle metoder for behandling av f.eks. smerter. Det er imidlertid viktig at tildelinger av forskningsmidler til utvikling av nye teknologiske metoder følges av tilstrekkelige midler til å vurdere klinisk nytteverdi. En større satsing på fokusert forskning av høy kvalitet på den kliniske nytteverdien av ikke-medikamentelle metoder i smertebehandling kan potensielt hjelpe svært mange pasienter - dels ved at adekvat behandling raskere vil kunne tas $\mathrm{i}$ bruk $\mathrm{i}$ helsevesenet, og dels ved at nye teknologiske metoder uten behandlingseffekt trolig ikke vil få grobunn i det alternative helsemarkedet.

\section{Kristian Bernhard Nilsen}

kristian.b.nilsen@ntnu.no

Kristian Bernhard Nilsen (f. 1974) er ph.d., førsteamanuensis ved Institutt for nevrovitenskap, Norges teknisk-naturvitenskapelige universitet, overlege ved Klinisk nevrofysiologisk laboratorium, Oslo universitetssykehus samt overlege i bistilling ved Avdeling for arbeidspsykologi og -fysiologi, Statens arbeidsmiljøinstitutt. Han er tilknyttet Formidlingsenheten for muskel- og skjelettlidelser ved Oslo universitetssykehus (FORMI). Forfatter har fylt ut ICMJE-skjemaet og oppgir ingen interessekonflikter

\section{Litteratur}

1. Hagen K, Linde M, Heuch I et al. Increasing prevalence of chronic musculoskeletal complaints. A large 11-year follow-up in the general population (HUNT 2 and 3). Pain Med 2011; 12: 1657-66.

2. Eriksen HR, Ursin H. Sensitization and subjective health complaints. Scand J Psychol 2002; 43: 189-96.

3. Frass M, Strassl RP. Friehs $\mathrm{H}$ et al. Use and acceptance of complementary and alternative medicine among the general population and medical personnel: a systematic review. Ochsner J 2012; 12: 45-56.

4. Fagerlund AJ, Bystad MK, Aslaksen PM. Transkranial likestrømsstimulering ved kroniske smerter. Tidsskr Nor Legeforen 2013; 113: 2266-9.

5. Meyerson BA, Linderoth B. Mechanisms of spinal cord stimulation in neuropathic pain. Neurol Res 2000; 22: 285-92.

6. Sluka KA, Walsh D. Transcutaneous electrical nerve stimulation: basic science mechanisms and clinical effectiveness. J Pain 2003. 4: 109-21.

7. Jensen KB, Kosek E, Wicksell R et al. Cognitive Behavioral Therapy increases pain-evoked activation of the prefrontal cortex in patients with fibromyalgia. Pain 2012; 153: 1495-503.

8. Plow EB, Pascual-Leone A, Machado A. Brain stimulation in the treatment of chronic neuropathic and non-cancerous pain. J Pain 2012; 13: 411-24.

9. Misra UK, Kalita J, Bhoi SK. High-rate repetitive transcranial magnetic stimulation in migraine prophylaxis: a randomized, placebo-controlled study. J Neurol 2013; e-publisert 21.8.2013.

10. Wang S-Y, Olson-Kellogg B. Shamliyan TA et al. Physical therapy interventions for knee pain secondary to osteoarthritis: a systematic review. Ann Intern Med 2012; 157: 632-44

11. Kadhim-Saleh A, Maganti $H$, Ghert $M$ et al. Is low-level laser therapy in relieving neck pain effective? Systematic review and meta-analysis. Rheumatol Int 2013; 33: $2493-501$. 